\title{
Investigating important factors influencing purchasing from chains
}

\author{
Naser Azad
}

Department of Management, Islamic Azad University, South Tehran Branch, Tehran, Iran

\begin{tabular}{l}
\hline A R T I C L E I N F O \\
\hline Article history: \\
Received October 1, 2011 \\
Received in Revised form \\
November, 14, 2011 \\
Accepted 15 December 2011 \\
Available online \\
19 December 2011 \\
\hline Keywords: \\
Advertisement \\
Chain stores \\
Marketing planning \\
Shahrvand stores
\end{tabular}
A B S T R A C T

\begin{abstract}
In this paper, we survey important factors, influencing customers to buy more from one of well known food market operating in capital city of Iran named Shahrvand. The survey studies the effects of six factors including customer's perception, persuasive factors, brand, customers' expectations, product's characteristics and special features of store on attracting more customers. We have distributed questionnaire among 196 customers who regularly visit stores and analyzed details of the data. The results indicate that customers' perception is the most important item, which includes eight components. Years of experience is the most important item in our survey followed by impact of color and working hours. Diversity of services is another factor, which plays the most important role followed by quality of services. Next, fidelity and brand are other most important factors and the name of store and risk are in lower degree of importance.
\end{abstract}

\section{Introduction}

Brands play important role on increasing the purchasing elasticity and there are many evidences, which confirm this fact (Bridges et al. 2006). There are literally tremendous efforts on measuring the effects of important factors on increasing marketing planning and increase the sales of products. Labeaga et al. (2007) investigated the behavioral loyalty towards store brands and their analysis shows that households who purchase from store brands (SBs) are much more likely to repeat purchase from the SBs when they have a purchase history of SBs.

Wu et al. (2011) studied the impact of store image and service quality on brand image and purchase intention for private label brands. They explained that the service quality of the store is also a vital issue impacting the purchasing behavior of customers. They reported that the impact of perceived risk on the purchase intension of private label brands (PLB) beats the price consciousness effect. According to $\mathrm{Wu}$ et al. (2011), as the price consciousness of a consumer increases, the buying intention for the PLB will increase too.

\footnotetext{
* Corresponding author. Tel. + 982122895719

E-mail addresses: dr.naserazad@yahoo.com (N. Azad) 
Many scholars have conceptually acknowledged the relationship between dress and customer expectations. Dress plays an important role and it is one of the tangibles, which are associated with a company's service. Shao et al. (2004) investigated the impacts of appropriateness of service contact personnel dress on customer expectations of service quality and purchase intention. Their studies indicated a significant impact of personnel dress on purchasing intention.

Verhagen and van Dolen (2009) investigated online purchase intentions using a multi-channel store image perspective. They reported several online store image variables, which significantly impact the intention to purchase, including online store merchandise, online store atmosphere and online store navigation. Kukar-Kinney and Walters (2006) studied the role of price-matching specifications in impacting store loyalty and anticipated that consumer price consciousness could moderate the impact of refund depth and scope on repeat store purchase behavior. In fact, the refund scope exerted a more positive impact on repeat store purchase behavior.

Dubé (2001) studied an intensity effects and psychological mechanisms on background music pleasure and store evaluation and realized that music plays an important role on increasing sales. Janjaap et al. (2004) investigated consumer assessments of store brands by investigating the effects of store image and product attributes. They explained that store brands could facilitate retailers to absorb customer traffic and build loyalty to the store by providing exclusive product lines and premium products. They explained that store image perceptions impact consumers' judgment of store brand quality in a positive sense, albeit to various degrees for many retailers (Saymana \& Rajub, 2004). Brand is normally involved with quality and many people believe that when they purchase a well known brand they will receive a good quality product (Roest \& Rindfleisch, 2010).

Kim et al. (2009) investigated the relationships among consumers' emotions, store image and purchases by a comprehensive survey on some retailers. There are some other studies, which indicate that customers' purchases are influenced mostly by the atmosphere of sellers' environment (Chebat et al., 2001). For instance, Grewal et al. (2003) studied the impacts of wait expectations and store atmosphere evaluations on patronage intentions in service-intensive retail stores. They also reported that among stores with presence of no music, classical music played in a luxury goods store will result in a more positive assessment of the store's atmosphere. Morrison et al. (2011) investigated instore music and aroma influences on shopper behavior and satisfaction. They reported that store environmental factors such as music and sound, lighting and color, and aroma could significantly help build the sensory impressions, which underlie these experiences. They believed a unique and effective atmospheric design is a vital expectation for retailers anticipating to create and retain a competitive advantage. In other words, sensory information from store atmospherics impacts cognitive and/or affective states, which in turn could alter shopping behaviors (Degeratu et al., 2000).

Price itself is an important issue for customers and there are many studies, which focus on the impact of price of selling price. Kukar-Kinney et al. (2011), for instance, investigated the role of price in the behavior and purchase decisions of compulsive buyers. Manning, K.C., \& Sprott (2007) investigated the impact of different price strategy to attract various groups of customers. Store environmental components such as music and sound, color and lighting, and aroma help create the sensory impressions, which underlie these experiences. Therefore, discovering a unique and effective atmospheric design is an objective for retailers wishing to build and maintain a competitive advantage (Morrison et al., 2011).

Many store chains are getting famous just because they could attract their customers' trust. Lau \& Lam (2008) investigated the effects of trusting and being trusted on team citizenship behaviors in chain stores. Another important factor is the existence of other shopping market on the vicinity of a 
particular store (Saymana \& Rajub, 2004; Martínez-Ruiz et al., 2010). Verhetsel (2005) studied the effects of neighborhood characteristics on store performance supermarkets versus hypermarkets.

The proposed model of this paper investigates different factors influencing people's attraction on purchasing a product such as people's vision from the store, past experiences of the chain, arrangement of goods, working hours, music, color of store, etc. The proposed study of this paper first presents details of the questionnaire of the survey in section 2. Section 3 presents details of the results and finally concluding remarks are given in the last to summarize the contribution of the paper.

\section{The proposed study}

The proposed study of this paper designs a questionnaire based on a Likert scale (Likert, 1932) where one represents the highest impact and five shows the lowest impact of a particular factor for choosing a shopping store from customers' perspective. We have distributed the questionnaire among 280 people and Cronbach alpha (Cronbach, 1951) was calculated as $87 \%$, which validates the survey.

To survey the results, we have used factor analysis on 28 questions of the survey, which helps us group items into six categories. The Kaiser-Meyer-Olkin measure of sampling adequacy is .84, Bartlett's Test of Sphericity approximation Chi-Square is also calculated as 2438. These results confirm our finding on six clusters. Each group consists of two, three or more variables, which indicate the priority of each factor. These six groups of factors demonstrate $56.34 \%$ of our observations and they are as follows,

\section{The results}

Fig. 1 shows the relative weights of each question. Factor $x_{1}$ includes eight variables of $(12,13,14$, 16, 19, 21, 22 and 28), which represents customer's perception from the chain store. Factor $x_{2}$ includes five variables of $(1,2,4,10$, and 15), which represents persuasive factors for attracting customers. Factor $x_{3}$ is associated with the brand of chain store.
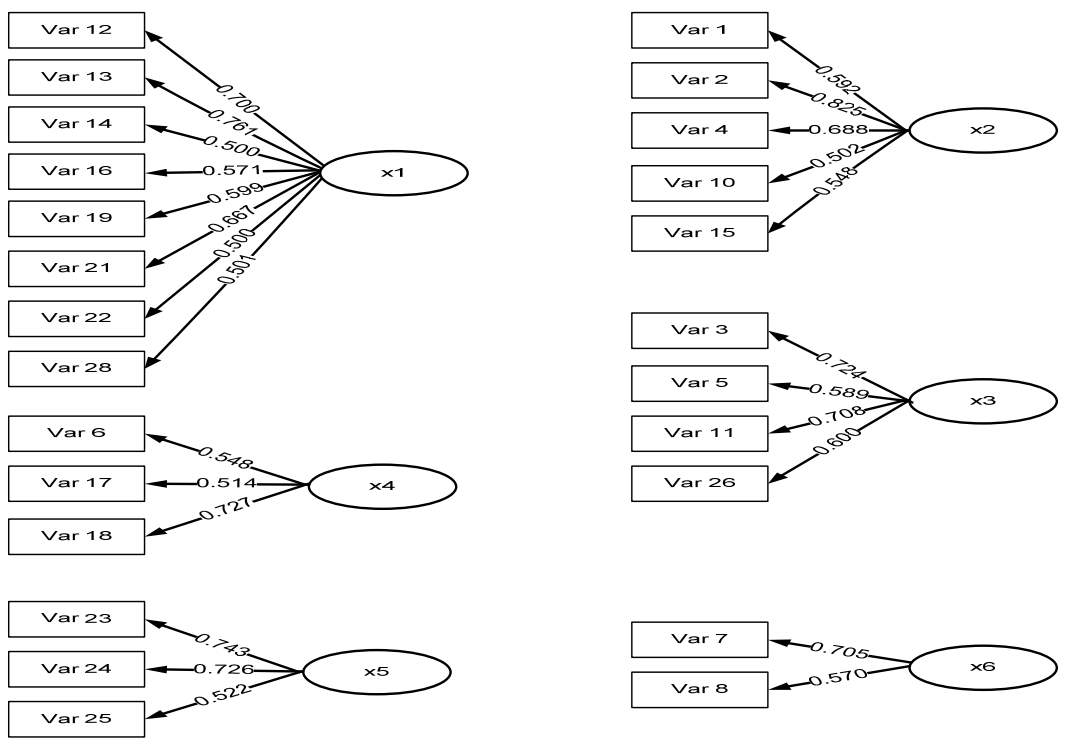

Fig. 1. Relative weight of each factor

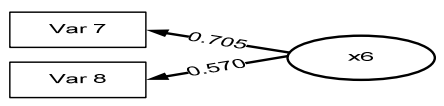


Factor $x_{3}$, which is associated with four variables of (3, 5, 11 and 26) covers brand of a store. Factor $x_{4}$, which is associated with three variables of $(6,17$, and 18$)$ covers customers' expectations. Factor $x_{5}$, includes variables $(23,24$ and 25$)$ and it covers product's characteristics. Finally, Factor $x_{6}$ with two variables of 7 and 8 is associated with special features of store.

The first factor is associated with customer's perception and includes eight items. Table 1 shows details of the first factor along with its weight factor.

\section{Table 1}

The results of factor analysis components for the first factor (Customer's perception)

\begin{tabular}{lllllllll}
\hline Factor & $\begin{array}{l}\text { years of } \\
\text { experience }\end{array}$ & $\begin{array}{l}\text { customers' } \\
\text { perception }\end{array}$ & $\begin{array}{l}\text { arrangement } \\
\text { of products }\end{array}$ & $\begin{array}{l}\text { working } \\
\text { hours }\end{array}$ & $\begin{array}{l}\text { role of } \\
\text { music }\end{array}$ & $\begin{array}{l}\text { Impact } \\
\text { of color }\end{array}$ & Smell & Harmony \\
\hline Weight & 0.70 & 0.761 & 0.50 & 0.571 & 0.599 & 0.667 & 0.50 & 0.501 \\
\hline
\end{tabular}

As we can observe from the results of Table 1, customers' perception is the most important item among these eight components. Years of experience is the most important item in our survey followed by impact of color and working hours. The other important factor is called persuasive items and the weights are summarized in Table 2.

\section{Table 2}

The results of factor analysis components for the second factor (Persuasive factor)

\begin{tabular}{llllll}
\hline Factor & Space & Services & Quality of services & $\begin{array}{l}\text { Price } \\
\text { specifications }\end{array}$ & Customer's feedback \\
\hline Weight & 0.592 & 0.825 & 0.688 & 0.502 & 0.548 \\
\hline
\end{tabular}

From the results of Table 2, we can conclude that diversity of services play the most important role followed by quality of services. Other factors are also considered important but not as much as the first item. The third factor is associated with brand of the product and details of the weighting and their specifications are summarized in Table 3.

Table 3

The results of factor analysis components for the third factor (Brand)

\begin{tabular}{lllll}
\hline Factor & Fidelity & Risk & Brand & Name \\
\hline Weight & 0.724 & 0.589 & 0.708 & 0.600 \\
\hline
\end{tabular}

It is clear from the results of Table 3 that fidelity and brand are the most important factors and the name of store and risk are in lower degree of importance. Next factor is associated with customer's expectations, which includes customer's awareness of prices with the weight of 0.548 , closeness to customer's residences with the weight of 0.514 and customers' expectation with the weight of 0.727 . The other factor is related to product's characteristics with three components.

The first one, the most important factor, is price and its brand with the weight factor of 0.743 , the second factor is characteristics of products with weight factor of 0.726 and the last item is reliability with relative weight factor of 0.522 . The other factor is associated with employees' uniform as well as the existence of online services and weights of these two factors are 0.705 and 0.570 , respectively. In summary, we have calculated the mean rank of the factors and Table 4 summarizes them. 
Table 4

The summary of ranking of six factors

\begin{tabular}{lllllll}
\hline Factor & 1 & 2 & 3 & 4 & 5 & 6 \\
\hline Weight & 3.53 & 2.64 & 4.67 & 2.71 & 3.03 & 4.41 \\
\hline
\end{tabular}

As we can observe from the results of Table 4, third factor, brand, is the most important factor, followed by employee's uniform and online services.

\section{Conclusion}

In this paper, we have explained important factors, influencing customers to buy more from one of well known food market operating in capital city of Iran, Shahrvand. The survey studied the influences of six factors including customer's perception, persuasive factors, brand, customers' expectations, product's characteristics and special features of store on attracting more customers. We have distributed questionnaire among 196 customers who regularly visit stores and analyzed details of the data. The results indicate that customers' perception is the most important item, which includes eight components. Years of experience was the most important item in our survey followed by impact of color and working hours. Diversity of services was another factor, which played the most important role followed by quality of services. Next, fidelity and brand are other most important factors and the name of store and risk are in lower degree of importance. The survey was focused on a single food market in Tehran and can be extended to a more comprehensive study by gathering data from different stores in the country using a more sophisticated system such as data mining.

\section{Acknowledgment}

The author would like to thank the anonymous referee for constructive comments on older version of this paper, which improved the quality of the paper.

\section{References}

Bridges, E., Briesch, R.A., Yim, C.K. (2006). Effects of prior brand usage and promotion on consumer promotional response. Journal of Retailing, 82, 295-307.

Chebat, J.C., Chebat, C.G., \& Vaillant, D. (2001). Environmental background music and in-store selling. Journal of Business Research, 54, 115-123.

Cronbach, L. J. (1951). Coefficient alpha and the internal structure of tests. Psychometrika, 16(3), 297-334.

Degeratu, A.M., Rangaswamy, A., \& Wu, J. (2000). The effects of brand name, price, and other search attributes. International Journal of Research in Marketing, 17 (1), 55-78.

Dubé, L., \& Morin, S. (2001). Background music pleasure and store evaluation: intensity effects and psychological mechanisms, Journal of Business Resource, 54(4), 107-113.

Grewal, D., Baker, J., Levy, M., Voss, G.B. (2003). The effects of wait expectations and store atmosphere evaluations on patronage intentions in service-intensive retail stores. Journal of Retailing, 79(4), 79, 259-268.

Janjaap, S., van Riel, A.C.R. \& Ambrosini, A.B. (2004). Consumer evaluations of store brands: effects of store image and product attributes. Journal of Retailing and Consumer Services, 11, 247-258.

Kim, J.E., Ju, H.W., Johnson, K.K.P. (2009). Sales associate's appearance: Links to consumers' emotions, store image, and purchases. Journal of Retailing and Consumers Services, 16, 407-413. 
Kukar-Kinney, M. \& Walters, R.G. (2006). The role of price-matching characteristics in influencing store loyalty. Journal of Business Research, 59, 475 - 482.

Kukar-Kinney, M., Ridgway, N.M., Monroe, K.B. (2011). The Role of Price in the Behavior and Purchase Decisions of Compulsive Buyers. Journal of Retailing and Consumer Services, 87, 2(3), 257-287.

Labeaga, J.M., Lado N., \& Martos, M. (2007). Behavioural loyalty towards store brands. Journal of Retailing and consumer services, 14, 347-356.

Lau, D., \& Lam, L. W. (2008). Effects of trusting and being trusted on team citizenship behaviors in chain stores. Asian Journal of Management \& Organization, 14(2), 141-154.

Likert, R. (1932). A Technique for the Measurement of Attitudes. Archives of Psychology, 140, 1-55.

Manning, K.C., \& Sprott, D. E. (2007). Multiple unit price promotions and their effects on quantity purchase intentions. Journal of Retailing, 83, 411-421.

Martínez-Ruiz, M.P., Jiménez-Zarco, A.I., \& Izquierdo-Yusta, A. (2010). Customer satisfaction's key factors in Spanish grocery stores: Evidence from hypermarkets and supermarkets. Journal of Retailing and Consumer Services, 17(4), 278-285.

Morrison, M, Gan, S., Dubelaar, C., \& Oppewal, H. (2011). In-store music and aroma influences on shopper behavior and satisfaction. Journal of Business Research, 64, 558-564.

Roest, H., \& Rindfleisch, A. (2010). The Influence of Quality Cues and Typicality Cues on Restaurant Purchase Intentions. Journal of Retailing and Consumer Services, 17(1), 10-18.

Saymana, S., \& Rajub, J. S. (2004). How category characteristics affect the number of store brands offered by the retailer : a model and empirical analysis. Journal of Retailing, 80, 279-287.

Shao, C.Y., Baker, J., Wagner, J.A. (2004). The effects of appropriateness of service contact personnel dress on customer expectations of service quality and purchase intention: The moderating influences of involvement and gender. Journal of Business Research, 57, 1164- 1176.

Verhetsel, A. (2005). Effects of neighborhood characteristics on store performance supermarkets versus hypermarkets. Journal of Retailing and Consumer Services, 12, 141-150.

Verhagen, T., \& van Dolen, W. (2009) Online purchase intentions: A multi-channel store image perspective. Information \& Management, 46, 77-82.

Wu, P.C.S., Yeh, G.Y.Y., Hsiao, C.R. (2011). The effect of store image and service quality on brand image and purchase intention for private label brands. Australasian Marketing Journal, 19, 30-39. 